\title{
Construction Safety Management Framework based on Smart Mobile
}

\author{
Moonseo Park ${ }^{1}$, Euijun $\mathrm{Kim}^{2}$, Hyun-Soo Lee ${ }^{3}$, and Kwang-Pyo Lee ${ }^{4}$ \\ Received July 12, 2011 / Accepted August 10, 2012
}

\begin{abstract}
With increasing number of serious construction disasters such as death, a safety management in real-time is more required recently. One of the ways to support the needs, a convergence with Information Technology (IT) has been noticed. Although number of inefficiencies including a limitation of IT equipment (weight, control inconveniences) has been concerned, data exchanging and processing fields have been improved at a wide range with an advance of mobile communication and an introduction of smart mobiles that are simple and convenient.

In this research, a framework is realized in connection with smart mobile to find the problems of current safety management and derive demands in order to support effective safety management. Two smart mobile applications, Safety Management application and Safety Guideline application, enable a real-time safety management and less re-work by provided safety information.
\end{abstract}

\section{Keywords: Safety Management, Smart Mobile, Application}

\section{INTRODUCTION}

\section{A. Background and Purpose}

As construction projects become high-rise and large recently, accidents in construction sites are transforming into irreversible catastrophes such as death, and effects of following damages are increasing. Under the situation, the importance of safety management is gaining more attention (Ministry of Labor 2007). Also, at construction sites, multi-functional tasks are under execution. Accordingly, related documentation on safety management is increasing and it is difficult to efficiently take care of a massive amount of the information. Realtime safety management at large and complicated construction sites is required to overcome problems mentioned above. As a measure to support this problemsolving in construction industry, IT-linked solutions have become the most reliable source nowadays. (Choi 2004).

Among many IT systems in construction industry, the most widely used ones are mobile systems for improvement of work efficiency and data saving. They include Palmtop, PDA (Personal Digital Assistant), and mobile phone with camera and tablet PCs. Although introducing IT at construction sites showed a number of benefits, there still exist inefficient factors such as equipment limitations stemming from weight, complexity and inconvenient operation, and the trouble of unproductive re-entering of data collected at sites by office manager. These factors make it hard to collect realtime information at sites and make decisions. Also, time and cost of system establishment, connectivity of wireless signals and information compatibility between hardware and software were pointed out as problems (Mills et al 2008).

On the other hand, today's developments in mobile communication enable real-time information exchange and processing using wireless transmissions over wide regions, and light and user-friendly smart mobile devices are applied to various fields. This is turning industrial paradigms. Shortly, smart mobiles are not just routine IT devices but have evolved into a level applicable to all industrial sectors. Such technological progress is anticipated to realize on-site real-time (for workers and site managers) information management which used to be only managed in office environment (on corporate level) (Yoon et al 2010).

Therefore, this research looks into issues with safety management of construction sites through interviews and pre-surveys with site specialists and working staff, and obtains requirements. Based on these, this research substantiates a framework that supports site safety management by linking with smart mobiles that are on the rise as the newest management tool thanks to recent technological progress.

\section{B. Research Method}

1) Analyze past researches on site safety management and convergence of IT with safety management. Also, review information on smart mobiles and analyze their applicability at construction sites.

\footnotetext{
${ }_{1}^{1}$ Professor, Seoul National University, mspark@snu.ac.kr (*Corresponding Author)

${ }^{2}$ Graduate Student, Seoul National University, ancn206@ hotmail.com

${ }^{3}$ Professor, Seoul National University, hyunslee@snu.ac.kr

${ }^{4}$ Graduate Student, Seoul National University, leekp86@ hotmail.com
} 
2) Analyze problems via surveys and interview with specialists.

3) Based on 2), evaluate and analyze requirements and get functions.

4) Materialize applications for safety management of construction sites.

5) Directly apply developed prototype to site, and validate effectiveness and feasibility through surveys and interview with specialists.

6) Using feedbacks from 5), materialize final applications.

\begin{tabular}{|c|c|c|}
\hline \multicolumn{3}{|c|}{ Preliminary r esearch } \\
\hline Safetymngt. & safetymngt. +IT & Sm ant m obile \\
\hline \multicolumn{3}{|c|}{$5 \%$} \\
\hline \multicolumn{3}{|c|}{ Problems analyze } \\
\hline \multicolumn{2}{|c|}{\begin{tabular}{|l|l} 
Interview with specialists & \\
\end{tabular}} & Survey \\
\hline \multicolumn{3}{|c|}{ Evaluate and analyze $r$ equir ements } \\
\hline \multicolumn{3}{|c|}{5} \\
\hline \multicolumn{3}{|c|}{ Materialize Framework } \\
\hline \multicolumn{3}{|c|}{ Develop of user interface andprototype } \\
\hline \multicolumn{3}{|c|}{5} \\
\hline \multicolumn{3}{|c|}{ Validation } \\
\hline \multicolumn{2}{|c|}{ Field test } & Interview with specialists \\
\hline \multicolumn{3}{|c|}{ Materialize final applications } \\
\hline
\end{tabular}

FIGURE I

RESEARCH PROCESS

\section{LITERATURE REVIEW}

\section{A. Definition of Safety Management and Working Processes}

Safety management of construction sites is construction management executed to prevent accidents that could occur from defects anticipated during construction processes. This is preventive engineering that prevents disasters and in turn protects workers from all sorts of hazards, reduces economic damages of construction companies, and controls smooth progress of construction and indirect expenses (Kwon 2009).

Generally, usual safety management routines in construction sites are as follows: (Shin 2007)

- Safety broadcasting (during commuting and lunch times)

- Safety assembly and training before work (5 $\min )$

- $\quad$ Check if safety protection tools and gears are put on by workers

- Safety training of new recruits, people with changed job tasks and people in need of special safety and health training

- $\quad$ Safety check and patrol

- Check status and conditions of harmful/dangerous machinery, tools and equipment

- Check cleanliness and neatness of the site at the end of task

- $\quad$ Check the office for fires and lights-off

- Maintain accident-related files
- Maintain safety-related documentation

$\bullet$

B. Review of Past Research Papers on Safety Management

Our review results were categorized into research purely focusing on safety management itself and research on IT applications to site safety management.

For research on safety management, Kwon (2009) analyzed basic components of safety management systems at current construction sites and reflected major points suggested by past researches on site safety management activities. Choi (1999) approached from an institutional perspective to establish site safety management. Also, research on improving safety check procedures through systematic approach (Yeom 2007) and computerized analysis and investigation of safety checklist for linked co-operation with project schedule on process diagrams were proposed (Yang 2004).

For research on IT applications to site safety management, research on safety and quality of buildings using RFID (Radio Frequency Identification) (Peinado 2009) was found. Also, there was a research on position tracking systems to manage site workers (Oh 2010). In addition, researches on RFID warning systems for prevention of unnecessary accidents (Schneider, 2003) and RTLS analysis and application to site (Lee 2010) were reviewed.

After reviewing researches on current safety management practices, it was found that researches have so far focused mainly on safety management improvement via institutional or systematic approaches, finding site applicability and performance evaluations. There is lack of studies on real-time information transmission (especially safety-related information) to support safety management practices.

\section{PDA (Personal Digital Assistant)}

The mobile technology such as PDA are the technologies that many researchers in the mid of 2000 have searched for an application in order to improve general interest elements of the construction industry such as shorting of air, decrease of unit prices, no-fault trial construction, non-accident plan, improvement of possibility of prediction, removal of wasteful elements, improvement of productivity and decrease of maintenance and management expenses, and is being utilized as being element technologies such as DAT(Data Acquisition Technology), ADC(Automation Data Collection) and USN(Ubiquitous Sensor Network). The $<$ Table $1>$ is the summary of Korean and international researches on the application of the mobile equipments on the construction field, and shows researches were performed in order to apply the technology especially PDA focused technology in many areas. 
TABLE I

RESEARCH ON THE APPLICATION OF THE MOBILE EQUIPMENTS

\begin{tabular}{|c|c|c|}
\hline Author & Contents & Note \\
\hline $\begin{array}{l}\text { Ahn } \\
\text { et al. } \\
\text { (2008) }\end{array}$ & $\begin{array}{c}\text { It suggests management system } \\
\text { using work efficiency management } \\
\text { system and delay factor based on } \\
\text { PDA }\end{array}$ & $\begin{array}{l}\text { Productivity } \\
\text { measurements }\end{array}$ \\
\hline $\begin{array}{l}\text { Kang et } \\
\text { al. } \\
(2003)\end{array}$ & $\begin{array}{l}\text { It investigates how PDA can be } \\
\text { used to improve efficiency and } \\
\text { effectiveness of construction } \\
\text { management process. It classifies } \\
\text { work scope into } 9 \text { catalogues }\end{array}$ & $\begin{array}{l}\text { Way of application at } \\
\text { construction site }\end{array}$ \\
\hline $\begin{array}{l}\text { Kim } \\
\text { et al. } \\
(2004)\end{array}$ & $\begin{array}{l}\text { It proposes a system using PDA } \\
\text { and Barcode to improve the labor } \\
\text { management.(interview and site } \\
\text { survey are conducted) }\end{array}$ & Labor management \\
\hline $\begin{array}{l}\text { X. Yu } \\
\text { et al. } \\
(2006)\end{array}$ & $\begin{array}{l}\text { It describes an example where a } \\
\text { PDA is used to replace a laptop } \\
\text { computer in the Time Domain } \\
\text { Reflectometry (TDR) } \\
\text { measurement system }\end{array}$ & Labor management \\
\hline $\begin{array}{l}\text { H. P. } \\
\text { Tserng } \\
\text { et al. } \\
(2005)\end{array}$ & $\begin{array}{l}\text { It demonstrates the effectiveness } \\
\text { of a bar-code-enabled PDA } \\
\text { application, called the mobile } \\
\text { construction supply chain } \\
\text { management(M-ConSCM) } \\
\text { System, that responds efficiently } \\
\text { and enhances the information flow } \\
\text { between offices and sites in a } \\
\text { construction supply chain } \\
\text { environment }\end{array}$ & $\begin{array}{c}\text { Materials } \\
\text { management }\end{array}$ \\
\hline $\begin{array}{l}\text { K. } \\
\text { Kimoto } \\
\text { et al. } \\
(2005)\end{array}$ & $\begin{array}{l}\text { It develops mobile computing } \\
\text { system such as; inspection system, } \\
\text { checklist and reference system, } \\
\text { position check system and progress } \\
\text { monitoring system }\end{array}$ & $\begin{array}{l}\text { Way of application at } \\
\text { construction site }\end{array}$ \\
\hline $\begin{array}{l}\text { J. Funk } \\
(2006)\end{array}$ & $\begin{array}{l}\text { It looks at the future of mobile } \\
\text { phone-based Intranet applications } \\
\text { using data from the Japanese } \\
\text { market and models of industry } \\
\text { evolution }\end{array}$ & $\begin{array}{l}\text { Way of application at } \\
\text { construction site }\end{array}$ \\
\hline $\begin{array}{l}\text { Y. Chen } \\
\text { et al. } \\
(2008)\end{array}$ & $\begin{array}{l}\text { It develops a model for the use of } \\
\text { mobile computing in the } \\
\text { management of on-site } \\
\text { construction information and } \\
\text { communication }\end{array}$ & $\begin{array}{c}\text { Knowledge } \\
\text { management system } \\
\text { based on mobile }\end{array}$ \\
\hline $\begin{array}{l}\text { Lee } \\
\text { et al. } \\
(2010)\end{array}$ & $\begin{array}{l}\text { It suggests the way which could } \\
\text { improve productivities of } \\
\text { superintendent with 'Construction } \\
\text { IT' through analysis of work } \\
\text { process of main superintendent } \\
\text { work }\end{array}$ & $\begin{array}{c}\text { Confirm } \\
\text { construction(quality, } \\
\text { progress) }\end{array}$ \\
\hline $\begin{array}{l}\text { Kim } \\
\text { et al. } \\
(2002)\end{array}$ & $\begin{array}{c}\text { It suggests efficient safety } \\
\text { management using PDA and } \\
\text { Internet.(diagnosis of building and } \\
\text { share information) }\end{array}$ & $\begin{array}{c}\text { Maintenance } \\
\text { management(Facility } \\
\text { safety management) }\end{array}$ \\
\hline
\end{tabular}

As we can see in the <Table 1>, though there have been many researches on the introduction of the PDA on the scene, it is currently being used on only 1 trial construction, which means the utilization of PDA on the construction field is incomplete. Also, when we preceded an interview with the working staff from the scene, the machine had faults in itself such as inconvenience on the use, the disappearance of the data during discharge, the small using time versus a long time of charging, deformity of the pixel of pictures, and so on. And, the obligatory repetitive work occurred that the person in charge has to type again the information she earned from the scene in the office, and due to the limitation of the equipments (Weight, cumbersomeness due to the multiple equipments, discomfort of the manipulation), real-time collection and the decision-makings are hard to be done, and due to which there were limitations in coping effectively with the various situations that occur in the construction field.

\section{Smart Mobiles}

Smart mobiles are mobile devices and services that rapidly and conveniently provide user-customized information based on precise evaluation of the situation. They are multi-functional and help users design a more rich and colorful life. Smart mobiles provide various functions such as application-based phone call, email, map search and augmented reality. Simply put, they enable functions, regardless of time and place, which were only available through PCs in the past.

As today's working styles are increasingly computerized and web-based, more general PCs are in use. As both demand for general PCs and necessity of computer works rise, users want to get work done anytime and anywhere. However, general PCs are not portable due to their size and do not fulfill the user's need for convenient computing by having ubiquitous web connection. On the contrary, smart mobiles have considerable capacities compared to general PCs and enable real-time access to information. Thanks to their small size, more users are turning to smart mobiles over general PCs.

As interpersonal data and information exchanges using smart mobiles become prevalent, close human networks are formed and working efficiencies improve. Wireless internet is anticipated to grow exponentially as it provides innovative values through sophisticated new services based on convergence with other services and technology such as location-based services, mobile office, commercials and payment. Location-based services are combining with augmented reality and social network service and growing rapidly. Furthermore, as mobile office that supports real-time processing of corporate tasks becomes popular, it is bringing in improvements in working styles.

Easy-to-use and light weight features along with compatibility with other IT devices enable personalized working environment even outdoors, and open-type operating systems help setting up user-specific interfaces.

Thus, in this research, the goal is support safety management by transmission of safety information and a smart mobile is employed as a tool of implementation.

\section{ANALYSIS OF SAFETY MANAGEMENT AND OBTAINING REQUIREMENTS}

\section{A. Survey Outline}

In this research, a survey was done to find out problems and inconveniences of site safety management. 
30 people from 3 construction sites of D company including site managers, office managers and working staff were surveyed. The outline of survey is shown in the following <Table $2>$.

TABLE II

INTERVIEW OUTLINE 1

\begin{tabular}{c|l}
\hline Classification & \multicolumn{1}{|c}{ Context } \\
\hline Purpose & $\begin{array}{l}\text { To find out problems and inconveniences of safety } \\
\text { management }\end{array}$ \\
\hline Period & $2011.01 .15-2011.01 .29$ \\
\hline Subject & $\begin{array}{l}\text { 30 people from 3 construction sites of D company } \\
\text { including site managers, office managers and } \\
\text { working staff }\end{array}$ \\
\hline Method & Visit site to interview and reply via E-mail \\
\hline
\end{tabular}

This survey consists of firstly surveyors' personal profile (years of work experience and job title), satisfaction level with current safety management practices and feasibility of using smart mobiles at sites.

\section{B. Identification and Analysis of Problems with Safety Management}

\section{1) Satisfaction Level with Current Safety Management Practices}

Before survey on site safety management, to test significance of the survey, 3 preliminary interviews were done with specialists. Based on these interviews, questionnaire was written up to survey site workers' satisfaction level with current site safety management practices. Meaningful results are summarized into following <Figure 2>.

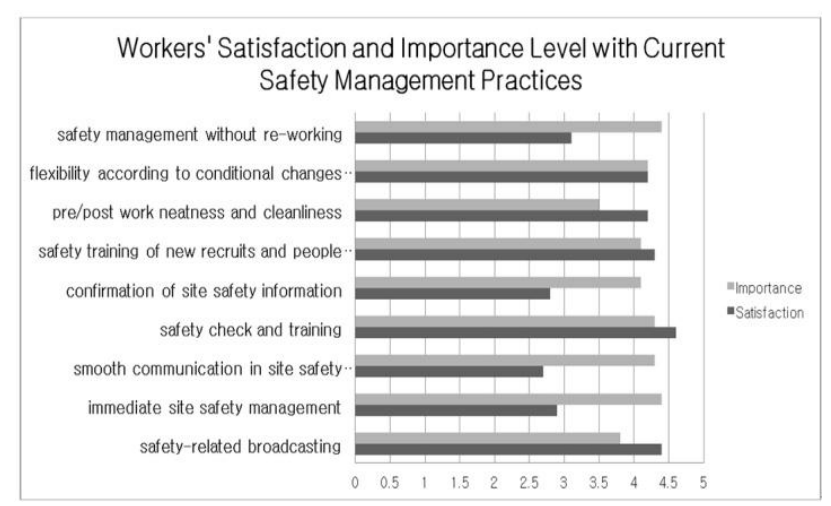

FIGURE II

WORKERS' SATISFACTION AND IMPORTANCE LEVEL WITH CURRENT SAFETY MANAGEMENT PRACTICES

Site working staff graded safety management without re-working as having importance of 4.4 points and satisfaction of 3.1 points on a 5-point scale. They evaluated flexibility according to conditional changes such as weather as importance of 4.2 and satisfaction of 4.2. On pre/post work neatness and cleanliness, ratings of 3.5 of importance and 4.2 of satisfaction were given by the staff. On safety training of new recruits and people with changed tasks, they gave 4.1 for importance and 4.2 for satisfaction. On confirmation of site safety information, 4.1 for importance and 2.8 satisfactions were given. For safety check and training, 4.3 of importance of 4.6 of satisfaction were answered. In addition, 4.3 important and 2.7 satisfied for smooth communication in site safety management, 4.4 important and 2.9 satisfied for immediate site safety management, and finally 3.8 important and 4.4 satisfied for safety-related broadcasting were reported respectively.

5 out of 9 question items (flexibility according to conditional changes such as weather, pre/post work neatness and cleanliness, safety training of new recruits and people with changed tasks and safety-related broadcasting) had ratios of satisfaction to importance of $1.000,1.200,1.024,1.070$ and 1.159 respectively, in which figures more than unity indicate the workers feel more satisfied about these items than how important they perceive each item. The remaining 4 out of 9 items (safety management without re-working, confirmation of site safety information, smooth communication in site safety management and immediate site safety management) had ratios of satisfaction to importance of $0.705,0.683,0.628$ and 0.659 respectively, in which figures less than unity indicate that the workers have less satisfaction levels on these items compared to how important they perceive them. Following <Table 3> is a summary of the above values.

TABLE III

SATISFACTION/IMPORTANCE OF SAFETY MANAGEMENT'S ITEMS

\begin{tabular}{l|c}
\multicolumn{1}{c}{ SATISFACTION/IMPORTANCE OF SAFETY MANAGEMENT'S ITEMS } \\
\hline \multicolumn{1}{c}{ Item } & $\begin{array}{c}\text { Satisfaction/ } \\
\text { Importance }\end{array}$ \\
\hline safety management without re-working & $\mathbf{0 . 7 0 5}$ \\
\hline $\begin{array}{l}\text { flexibility according to conditional changes such as } \\
\text { weather }\end{array}$ & 1.000 \\
\hline pre/post work neatness and cleanliness & 1.200 \\
\hline $\begin{array}{l}\text { safety training of new recruits and people with changed } \\
\text { tasks }\end{array}$ & 1.024 \\
\hline confirmation of site safety information & $\mathbf{0 . 6 8 3}$ \\
\hline safety check and training & 1.070 \\
\hline smooth communication in site safety management & $\mathbf{0 . 6 2 8}$ \\
\hline immediate site safety management & $\mathbf{0 . 6 5 9}$ \\
\hline safety-related broadcasting & 1.158 \\
\hline
\end{tabular}

The items for which the ratio of satisfaction to importance was less than 1 are harmful to the efficiency of site safety management. Thus, each of these areas can be said to be in need of improvement.

\section{2) Identification and Analysis of Problems with Safety Management}

This section is a concrete questionnaire of problems of the above 4 items (safety management without reworking, confirmation of site safety information, smooth communication in site safety management and immediate site safety management) that are thought to have room for improvement.

Firstly, in the survey item on reworking safety management, more than half (20) of 30 people said that the degree of problem is 'a little high or high'. 5 people said 'normal' and 5 people said 'low or a little low'. Following <Figure $3>$ is the graph of the result. 


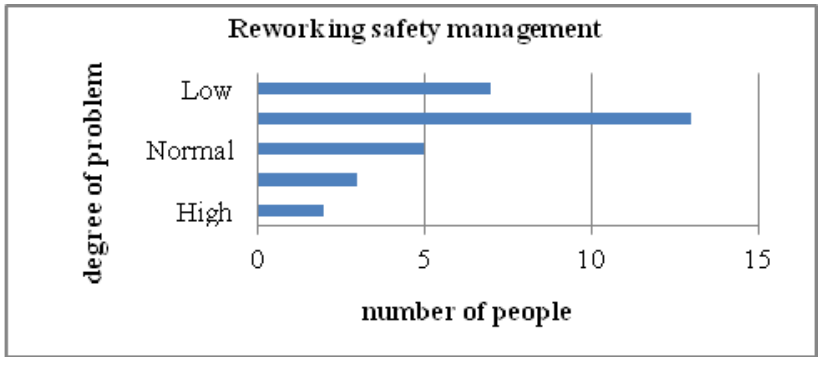

FIGURE II

REWORKING SAFETY MANAGEMENT

It is found that the origins of this problem are factors such as hand-writing documents at sites and re-writing in office, and uploading once again into company's Project Management Information System.

On the survey item of difficulty with confirmation of site safety information, 12 people viewed the degree of this problem as 'high or a little high'. 8 people said 'normal', 10 people answered 'low or a little low'. Following <Figure 4> is the graph of the result.

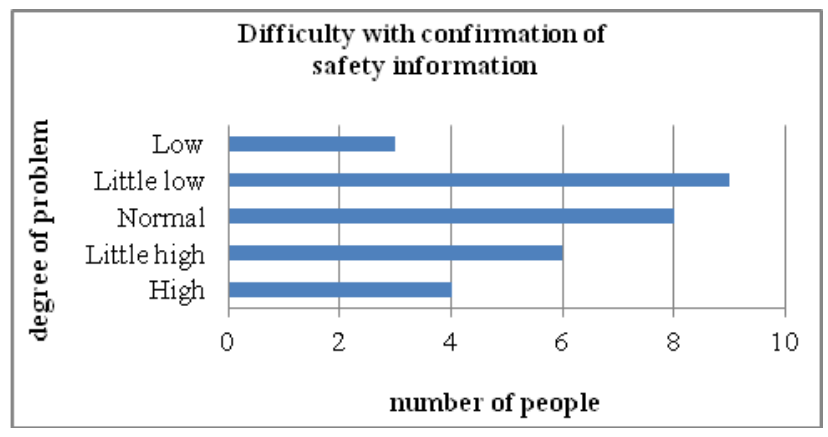

FIGURE IV

DIFFICULTY WITH CONFIRMATION

The origins of this problem are the difficulty of site safety manager to confirm safety procedures according to different working projects, new technology and engineering processes. For this, manuals and specifications are accompanied in sites, but they are heavy in weight and troublesome, causing obstruction to work.

On the item of smooth communication in site safety management, 15 people said the degree of problem is 'high or a little high', 10 said 'normal' and the other 5 said 'low or a little low'. Following <Figure 5> is the graph of the result.

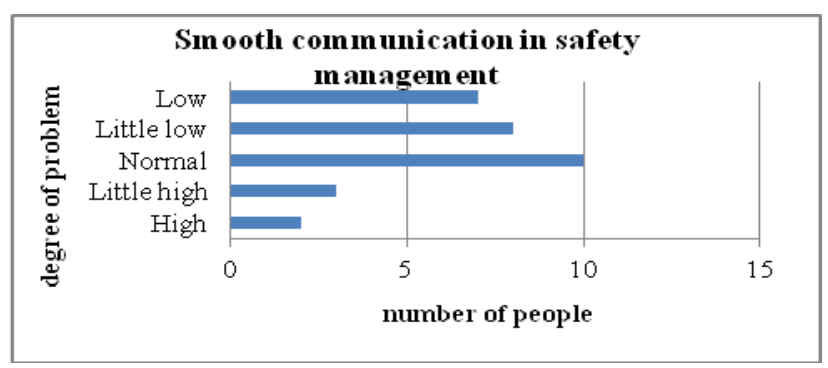

FIGURE V

SMOOTH COMMUNICATION IN SAFETy MANAGEMENT
This problem stems from a situation in which there could exist communication problems between construction company and subcontractors. Also, this problem can be caused by people trying to avoid the responsibility of site safety management.

Lastly, on the item of difficulty with immediate safety management, 13 people said 'high or a little high', 8 said 'normal' and 9 said 'low or a little low'. Following <Figure $6>$ is the graph of the result.

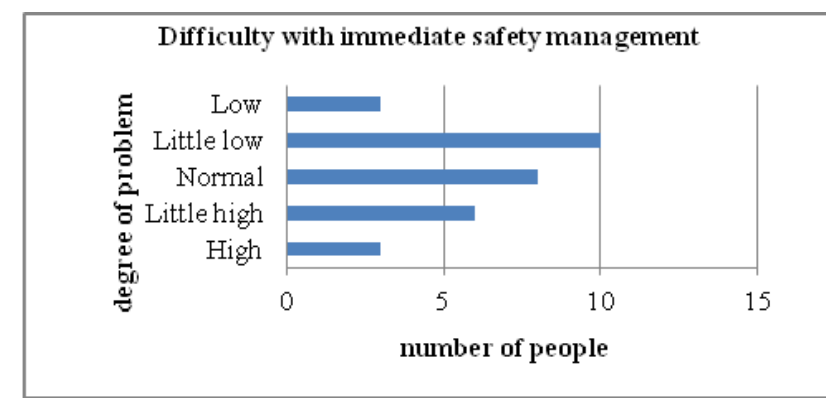

FIGURE VI

SMOoth Communication In SAFETy MANAGEMENT

This is possibly due to poor feedbacks or action among people in charge when a safety-related accident or recommendation occurs, making it hard to immediately respond to the situation.

\section{Obtaining Requirements for Safety Management}

Requirements for site safety management were selected and obtained from problem analysis of the survey. As a result of analyzing problems site safety management found from the above questionnaires, requirements were broken into 3 major categories.

Firstly, a real-time safety management is needed. There are matters in site safety management that require immediate decision and action (announcement and feedback of safety guidelines and recommendations/warnings). However, results of our problem analysis indicate that these matters actually contribute to decreasing efficiency of safety management practices due to many constraints (communication among involved parties, poor real-time management and etc). Therefore, elements that can enhance immediate confirmation of safety conditions, smooth and efficient communication in case of emergency (safety accidents or recommendations/warnings), and avoidance of responsibility for safety management are necessary.

Secondly, immediate use of safety information at sites. Even the most experienced safety managers are not knowledgeable about every safety guideline, cause and cautions of safety disasters and especially everdeveloping engineering processes and technology. Naturally, it is a much heavier burden for the junior safety manager. To solve this, people carry with themselves all sorts of specifications, manuals and checklists which are all too cumbersome, complex and inconvenient. At sites, elements that enable convenient and especially immediate confirmation of safety-related information are necessary. 
Thirdly, to eliminate complexities in work, most construction companies have applied PMIS for lean corporate management. Nevertheless, making up handwritten documents and re-inputting them into the PMIS server has been pointed out as a major problem. To solve this, elements for safety management without repetition and duplication of work are necessary.

\section{SAFETY MANAGEMENT FRAMEWORK USING SMART MOBILES}

\section{A. Definition of Safety Management Application based on Smart Mobiles}

Smart mobile applications (site safety management application and safety guideline application) can be a solution to the above-mentioned 3 requirements for site safety management. The <Figure 7> shows the correlation between the requirements and 2 smart mobile applications.

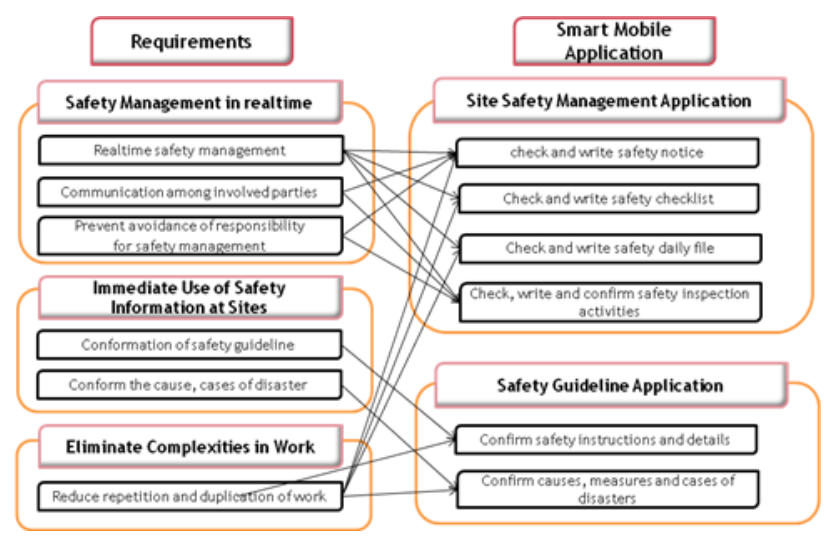

FIGURE VII

CORRELATION BETWEen THE REQUIREMENTS AND SMART MOBILE APPLICATION

Site safety management application is developed with focus on safety management matters that need to be dealt with immediately. They allow checking and writing safety-related notices from corporate headquarters or office any time, and daily safety activities (checking and writing safety checklist and files) can be done conveniently using smart mobiles. Also, once safetyrelated recommendation or warning is given, smart mobiles can help immediate sharing information and follow-up action. Using smart mobile, real-time safety management is possible without having to re-enter data in office. Thus, re-working jobs are remarkably reduced. The <Figure $8>$ below is a visualization of flow and exchange of information between the user and the corporate server.

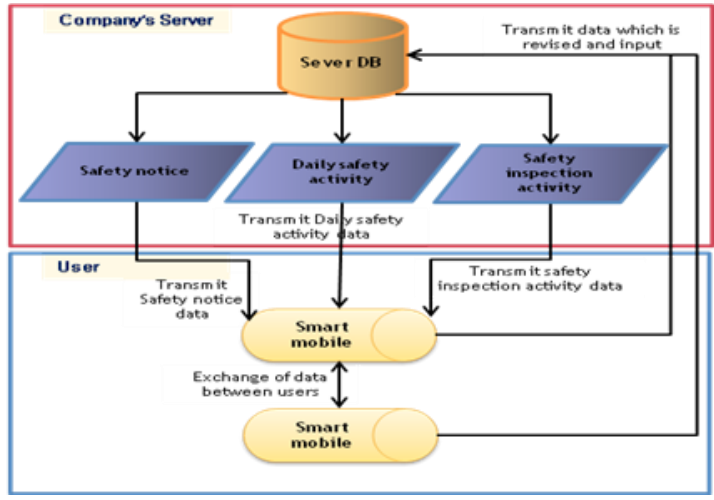

FIGURE VIII

VisuALIZATION OF FLOW AND EXCHANGE OF INFORMATION BETWEEN THE USER AND THE CORPORATE SERVER AT SiTE SAFETY MANAGEMENT APPLICATION

Moreover, safety guideline application IS developed with focus on confirmation of safety information at sites. The on-site worker can confirm safety guidelines and details of his chosen construction project. 33 safety guidelines from Korea's Industrial Safety and Health Corporation are organized into 11 major working activities.

$<$ Table $4>$ is an example of the classified data.

TABLE IV

EXAMPLE OF THE CLASSIFIED DATA

\begin{tabular}{|c|c|}
\hline Activity & Safety guidelines \\
\hline Earth work & $\begin{array}{l}\text { - TOP DOWN method } \\
\cdot \text { Excavation } \\
\cdot \text { Underground structure excavation } \\
\text { - Explosion }\end{array}$ \\
\hline $\begin{array}{c}\text { Retaining wall and pile } \\
\text { work }\end{array}$ & - Case in Place pile method \\
\hline Masonry work & $\begin{array}{l}\text { Masonry work safe working } \\
\text { technique }\end{array}$ \\
\hline $\begin{array}{l}\text { Reinforced concrete } \\
\text { work }\end{array}$ & $\begin{array}{l}\text { - Shore structure analysis } \\
\text { - Steel structure } \\
\text { - Slip-form }\end{array}$ \\
\hline
\end{tabular}

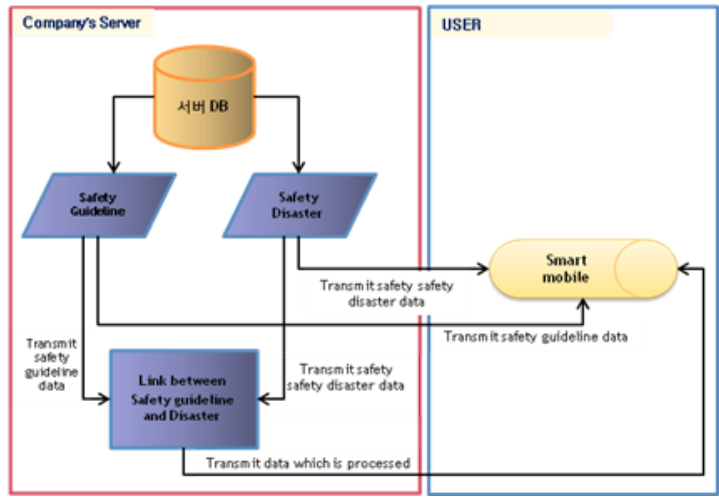

FIGURE IX

VisuALIZATION OF FLOW AND EXCHANGE OF INFORMATION BETWEEN THE UsEr AND THE CORPorate SERVER AT SAFETy GuIDELINE APPLICATION 


\section{B. Implementation of Site Safety Management Application}

To realize this application, necessary functions are comprised of system, write, confirmation and pushmessages. System is divided into a login function by selecting project information and downloading relevant information and a code-managing function through organizational information. Also, there is the write function of video recording, text and uploading and a confirmation function by list or text search. Also, there is the push message function that the user requested to reply can check up on. The <Figure 10> below shows a comprehensive functional diagram.

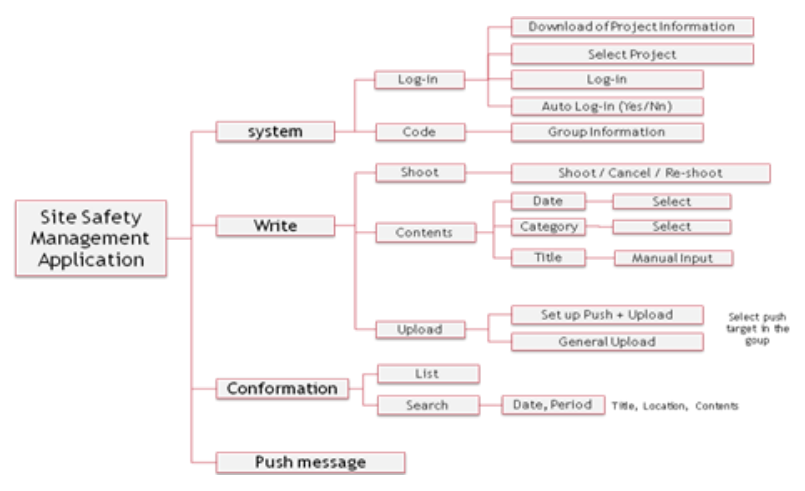

FIGURE X

COMPREHENSIVE FunCTIONAL DiAGRAM OF SITE SAFETY MANAGEMENT APPLICATION

To share information on various and complex information generated at sites, PMIS (Project Management Information System) was applied. The site safety management application of this research is linked with the PMIS to facilitate more effective site safety management practices. Each function and menu is linked with the PMIS server as shown in <Figure 11> below.

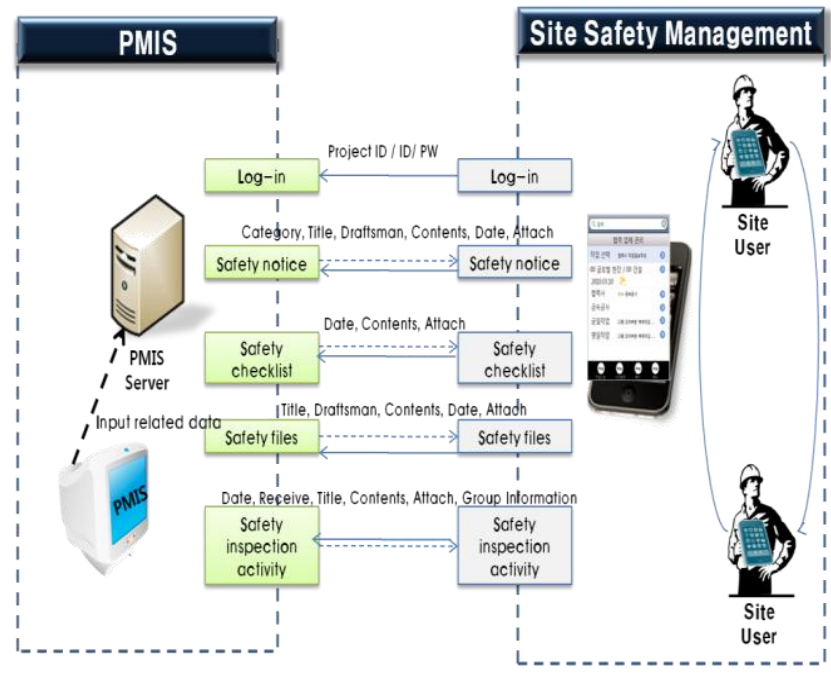

FIGURE XI

Link BETWEen PMIS AND Site SAFETy MANAGEMENT

Flow of the site safety management application is composed of 3 components including safety notice, daily safety activities and management of safety checking activities. The user can go into the chosen menu to check up on each content, write up and transmit information.

Safety notice menu enables the user to check up on notices from site office and corporate headquarters any time and write up content.

Daily safety activities menu is divided into safety checklist and safety file. Instead of carrying the safety checklist paper around sites and bringing it back to office to re-enter content into computer, once the user inputs data directly at site, it gets transmitted to the server. Likewise, the user can put in simple content and take a photograph and send it to the server.

Lastly, in the management of safety checking activities menu, the user can write up content and take a photograph and send it to a relevant person if a problem arises instead of communicating through radio and telephone and then documenting the situation in office. The relevant person, having received a push message, can handle the problem and take a photograph and send it to the manager and server real-time.

Site safety management application is expected to increase real-time communication, working efficiencies and conveniences while reducing re-workings.

\section{Implementation of Safety Guideline Application}

To realize the above-mentioned safety guideline application, system, selection and search functions are necessary. System function makes codes out of large construction projects and disasters and matches them with one another. Selection function enables selection of working instructions and details according to construction projects as well as cause of disaster, corrective action and cases. Lastly, search function enables the user to type up and search safety guidelines and disasters. <Figure 12> below is a comprehensive functional diagram.

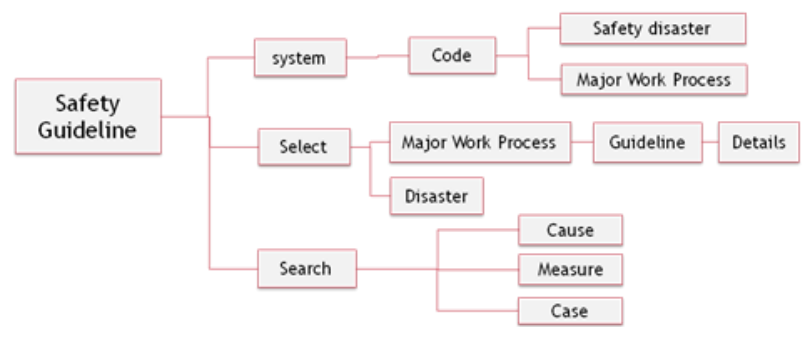

FIGURE XII

COMPREHENSIVE FunCTIONAL DiAGRAM OF SAFETY GUIDELINE APPLICATION

Flow of this application is divided into safety guidelines for each construction project type and direct confirmation of each disaster type. The user can select his chosen menu to check up on safety guidelines and disasters.

Safety guidelines for each construction project type, which is the first menu of this application, are configured in a way that once the user selects a construction project out of a larger unit construction project and selects one among the safety guidelines, details can be confirmed. 
The second menu, direct confirmation of each disaster type, allows the user to directly select the type of disaster (falling, collapse, fire and etc), relevant sections (cause of disaster, safety corrective actions, and disaster cases) and details accordingly.

Safety guideline application exempts the safety manager from having to carry on heavy manuals and documentation and conveniently take care of all safetyrelated information in one smart mobile. This reduces trouble of work and increases convenience and efficiency of site safety management in turn.

\section{VALIDATION OF SAFETY MANAGEMENT FRAMEWORK}

Validation of efficiency of site safety management using smart mobiles is divided into field testing and interview with specialists.

\section{A. Field Test}

To validate the effectiveness of safety management framework, field test is performed. The detail about construction site is as below <Table 5>.

TABLE $\mathrm{V}$

CONSTRUCTION SITE's DETAIL

\begin{tabular}{c|l}
\hline \multicolumn{1}{c}{ CONSTRUCTION SITE'S DETAIL } \\
\hline $\begin{array}{c}\text { Ordems } \\
\text { organization }\end{array}$ & $\begin{array}{l}\text { Contents } \\
\text { Union }\end{array}$ \\
\hline State of order & Joint-Venture contract \\
\hline Size & $\begin{array}{l}\text { Total }-3,293 \text { households, 51 buildings, 3 stories } \\
\text { below and 35 above the ground }\end{array}$ \\
\hline $\begin{array}{c}\text { Number of } \\
\text { households }\end{array}$ & $\begin{array}{l}39 \mathrm{~m}^{2}: 553,47 \mathrm{~m}^{2}: 76,59 \mathrm{~m}^{2}: 357,84 \mathrm{~m}^{2}: 1,657 \\
120 \mathrm{~m}^{2}: 504,153 \mathrm{~m}^{2}: 138,201 \mathrm{~m}^{2}: 8 \\
\text { total }: 3,293\end{array}$ \\
\hline Area size & $157,001.60 \mathrm{~m}^{2}$ \\
\hline Total area & $575,494.03 \mathrm{~m}^{2}$ \\
\hline Period & $2009.10 .06 \sim 2012.10 .05$ \\
\hline $\begin{array}{c}\text { Construction } \\
\text { cost }\end{array}$ & $653,176,000,000$ won \\
\hline
\end{tabular}

Comparison of existing as-is processes with to-be processes from using the application was done to validate the utility of this research. <Figure 13> below shows existing as-is processes and processes expected to change when the application is implemented.

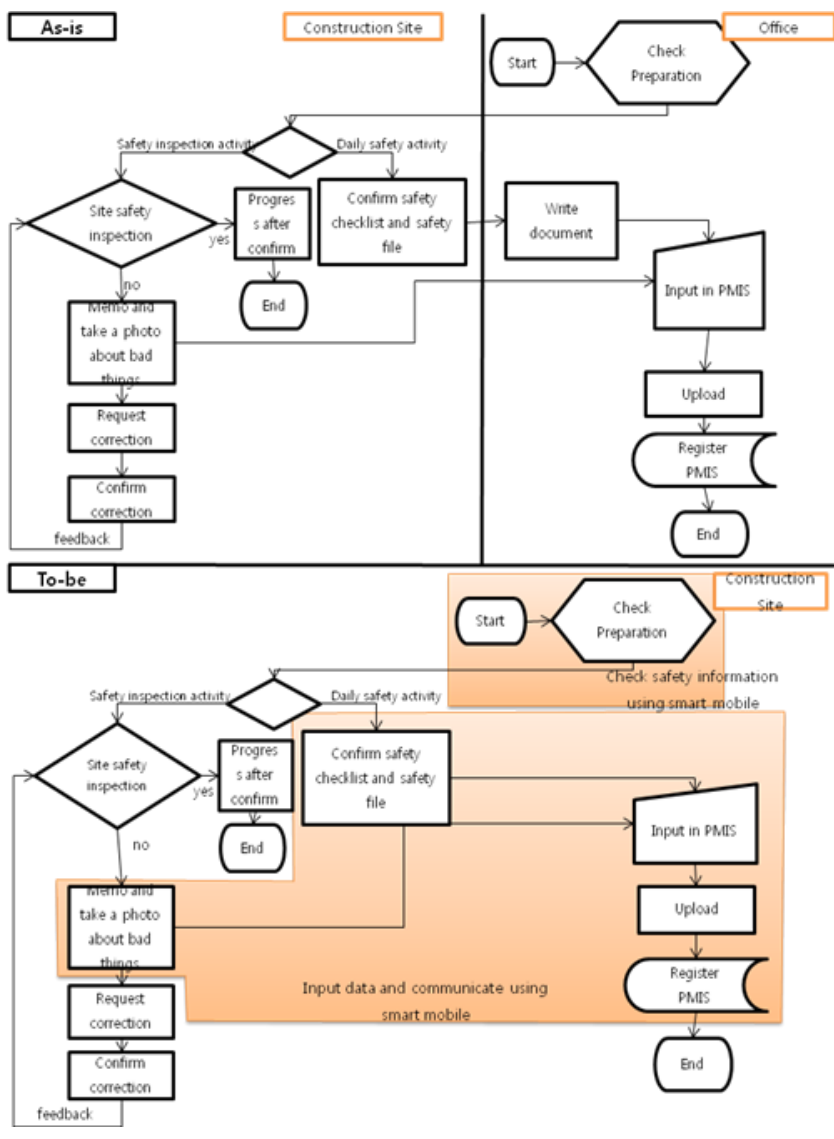

FIGURE XIII

As-Is AND To-Be Model In SAFETy MANAGEMENT

Whereas existing as-is processes had many re-workings and problems with real-time safety management due to two different sources (site and office), smart mobile applications enable the direct safety management at site without having to go back and forth between office and site. The field testing results show improvements in efficiency from $32.5 \%$ to $36.5 \%$ on safety checking activities, from $31.8 \%$ to $36.8 \%$ on daily safety activities. $<$ Table 6> below is detailed time reduction effects as a result of field testing.

TABLE VI

\begin{tabular}{|c|c|c|c|}
\hline \multicolumn{4}{|c|}{ RESUlt OF FIELD TEST } \\
\hline \multicolumn{2}{|l|}{ As-Is } & \multicolumn{2}{|l|}{ To-Be } \\
\hline \multicolumn{4}{|c|}{ Safety Inspection Activity } \\
\hline Phase & Time(s) & Phase & Time(s) \\
\hline Find safety problem & - & Find safety problem & - \\
\hline Memo and take photo & 60 & Access application & 30 \\
\hline $\begin{array}{l}\text { Request a correction } \\
\text { and confirm }\end{array}$ & $60-120$ & $\begin{array}{l}\text { Take a photo and } \\
\text { input contents }\end{array}$ & 150 \\
\hline Write document & $\begin{array}{l}120- \\
180\end{array}$ & Upload & 30 \\
\hline Access PMIS & 30 & $\begin{array}{l}\text { Request a correction } \\
\text { and confirm }\end{array}$ & $60-120$ \\
\hline Input pertinent data & 120 & & \\
\hline Upload & 10 & & \\
\hline TOTAL & $\begin{array}{l}400- \\
520\end{array}$ & TOTAL & $\begin{array}{l}270- \\
330\end{array}$ \\
\hline
\end{tabular}




\begin{tabular}{l|l|l|l}
\hline \multicolumn{4}{c}{ Daily Safety Activity } \\
\hline \multicolumn{1}{c|}{ Phase } & Time(s) & \multicolumn{1}{c}{ Phase } & Time(s) \\
\hline $\begin{array}{l}\text { Examine safety } \\
\text { checklist }\end{array}$ & $\begin{array}{l}120- \\
180\end{array}$ & Access application & 30 \\
\hline $\begin{array}{l}\text { Write safety checklist } \\
\text { and document }\end{array}$ & 100 & $\begin{array}{l}\text { Examine safety } \\
\text { checklist }\end{array}$ & $\begin{array}{l}180- \\
240\end{array}$ \\
\hline Access PMIS & 30 & Upload & 30 \\
\hline Input pertinent data & 120 & & \\
\hline Upload & 10 & & $\mathbf{2 4 0 -}$ \\
\hline TOTAL & $\begin{array}{l}\mathbf{3 8 0}- \\
\mathbf{4 4 0}\end{array}$ & TOTAL & $\mathbf{3 0 0}$ \\
\hline
\end{tabular}

of work, it leaves the worker in a defenseless state. Therefore, increase in the risk of a safety accident is worried.

The above-mentioned problems are anticipated to be solved by firstly organizing information such as safety guidelines and optimizing UI to enhance readability, secondly increasing convenience by using static charge touch pen or glove, thirdly coming up with new site safety guidelines in consideration of smart mobiles, training them and facilitating fast operation through coding of processes.

\section{CONCLUSION}

\section{B. Interview}

Interviews were done with specialists who actually used the smart mobile prototype at sites to validate effectiveness of the research. Interviewees consisted of 5 site safety management specialists with over 10 years of experience and 4 specialists who research and guide safety management. Interviews consisted of explanation of the application and getting feedbacks from the specialists. To objectify their opinions, a survey was also done on how well the application will satisfy requirements of the site. Degree of satisfaction was determined on a 5 -point scale with 5 being most satisfied and 1 being least satisfied. $\langle$ Table 7$\rangle$ below is the result of the survey.

TABLE VII

RESULT OF INTERVIEW WITH SPECIALISTS

\begin{tabular}{|c|c|c|c|c|c|}
\hline \multirow[b]{2}{*}{ Category } & \multirow[b]{2}{*}{ Item } & \multicolumn{3}{|c|}{ Satisfaction level } & \multirow[b]{2}{*}{ Avg } \\
\hline & & $\begin{array}{c}\text { Satisfied } \\
(4-5)\end{array}$ & $\begin{array}{c}\text { Unsatisfied } \\
(1-2)\end{array}$ & \begin{tabular}{|c|} 
Normal \\
$(3)$
\end{tabular} & \\
\hline \multirow{3}{*}{$\begin{array}{l}\text { real-time } \\
\text { safety } \\
\text { manageme } \\
\text { nt }\end{array}$} & $\begin{array}{l}\text { Real-time safety } \\
\text { management }\end{array}$ & 9 & 0 & 0 & 4.44 \\
\hline & $\begin{array}{l}\text { Communication } \\
\text { among involved } \\
\text { parties }\end{array}$ & 8 & 1 & 0 & 4.00 \\
\hline & $\begin{array}{l}\text { Prevent } \\
\text { avoidance of } \\
\text { responsibility } \\
\text { for safety } \\
\text { management }\end{array}$ & 8 & 0 & 1 & 4.22 \\
\hline \multirow{2}{*}{$\begin{array}{l}\text { immediate } \\
\text { use of } \\
\text { safety } \\
\text { informatio } \\
n\end{array}$} & $\begin{array}{l}\text { Conformation of } \\
\text { safety guideline }\end{array}$ & 7 & 1 & 1 & 3.78 \\
\hline & $\begin{array}{l}\text { Conform the } \\
\text { cause, cases of } \\
\text { disaster }\end{array}$ & 6 & 1 & 2 & 3.78 \\
\hline $\begin{array}{l}\text { eliminate } \\
\text { complexiti } \\
\text { es in work }\end{array}$ & $\begin{array}{l}\text { Reduce } \\
\text { repetition and } \\
\text { duplication of } \\
\text { work }\end{array}$ & 8 & 0 & 1 & 4.33 \\
\hline
\end{tabular}

Although the effectiveness of the application was validated through interview with specialists, following problems were pointed out.

Firstly, the screen is too small for reading safety guidelines causing inconvenience.

Secondly, the smart mobile device is impossible to operate when gloves are worn, thereby adding an extra trouble of having to take off gloves.

Thirdly, if the mobile application is used in the middle

\section{A. Research result}

This research proposes a framework for site safety management based on smart mobiles.

1. Pre-interviews with specialists were done to make up a questionnaire for safety managers and working staff to survey degrees of satisfaction and importance of current site safety management practices.

2. Based on the survey results, problems were identified and analyzed. Requirements obtained from problem analysis indicate there are needs for real-time safety management, immediate use of safety information at sites and reduction of repetitive working procedures.

3. Based on 2, two smart mobile applications are proposed.

4. Site safety management application. The application is designed with emphasis on safety management aspects that will benefit most from real-time processing such as safety notice, checklist makeup and upload, checking today or tomorrow's safety files and daily safety activities.

5. Safety guideline application. This application is designed to enable immediate on-site checking of safety information if needed such as safety guidelines and details per construction project type and causes, corrective action and cases per disaster.

6. Through the field test bed, developed applications are validated as to how much time reduction is accomplished by changes in processes via smart mobile applications. Afterwards, interviews with specialists validate to what extent the previously obtained requirements are fulfilled.

\section{B. Contributions and Future Researches}

The site safety management application enables realtime safety management at sites and is expected to improve real-time communication, working efficiencies and convenience while reducing re-workings. Also, safety guideline application exempts the safety manager from having to carry on heavy manuals and documentation and conveniently take care of all safety-related information in one smart mobile. This reduces trouble of work and increases convenience and efficiency of site safety 
management in turn.

For future researches, final development is necessary based on modifications reflecting feedbacks by specialists.

\section{REFERENCES}

[1] S. Ahn, J. Yu, C. Kim, "A Study of Work Efficiency Management System Using PDA", Journal of the Architectural Institute of Korea, vol. 24, no. 11, pp. 143-151, 2008

[2] S. Bowden, A. Dorr, A. Thorpe, C.J. Anumba, P. Gooding, "Making the Case for Mobile IT in Construction", ASCE International Conference on Computing in Civil Engineering 2005, Cancun, Mexico, pp. 1-12, 2005.

[3] S. Bowden, A. Dorra, T. Thorpeb, C. Anumbac, "Mobile ICT support for construction process improvement", Automation in Construction, vol. 15, no. 5, pp. 664-676, 2006.

[4] Y. Chen, J.M. Kamara, "Using mobile computing for construction site information management", Engineering, Construction and Architectural Management, vol. 15, no. 1, pp. 7-20, 2008.

[5] Y. Cho, "Applications for Portable Wireless Device on Construction Site", the Architectural Institute of Korea, vol. 51, no. 6, pp. 52-53, 2007.

[6] C. Choi, "A case study and future directions of Radio Frequency Identification system in $\mathrm{A} / \mathrm{E} / \mathrm{C}$ industry", Korea Institute of Construction Engineering and Management Academy Conference, pp. 145-149, 2004.

[7] M. Choi, "Improvement on construction safety management framework", Construction Economy Research Institute of Korea, 1999.

[8] A. Dong, M.L. Mahera, M.J. Kim, N. Guc, X. Wanga, "Construction Defect Management using a Telematic Digital Workbench", Automation in Construction, vol. 18, no. 6, pp. 814824, 2009.

[9] J.L. Funk, "The future of mobile phone-based Intranet applications: A view from Japan", Technovation, vol. 26, no. 12, pp. 1337-1346, 2006

[10] J. Irizarry, T. Gill, "Mobile Application for Information Access on Construction Jobsites", ASCE International Workshop on Computing in Civil Engineering, Austin, TX, USA, pp. 176-185, 2009.

[11] J. Jung, T. Kim, H. Kim, Y. Jo, "A study on the improvement of current construction safety management system", Korea Institute of Construction Engineering and Management Academy Conference, pp. 691-694, 2007.

[12] M. Kang, K. Shin, J. Kim, "A study on Efficiency Increase of Construction Field Operations Using PDA", the Architectural Institute of Korea Academic Conference (Planning), vol. 23, no. 1, pp. 807-810, 2003.

[13] B. Kim, D. Kim, U. Lee, B. Han, K. Kang, "Establishment of Integrated Instrumentation Management System for Retaining Wall via Internet and PDA", Journal of the Architectural Institute of Korea, vol. 21, no. 11, pp. 183-190, 2005.

[14] S. Kim, U. Lee, K. Kang, "The study on the Proposals for Application to Information Technology in Field Construction", Korea Institute of Construction Academic Conference, vol. 5 no. 1, pp. 207-210, 2005.

[15] T. Kim, C. Park, "A Scheme for Improving Site Labor Management using Information Management Technology", the Architectural Institute of Korea Academic Conference (Structure), vol. 24, no. 1, pp. 491-494, 2004.

[16] Y. Kim, "PDA prototype system for construction facilities safety supervision", KonKuk University, 2003.

[17] Y.S. Kim, S.W. Oh, Y.K. Cho, J.W. Seo, "A PDA and wireless web-integrated system for quality inspection and defect management of apartment housing projects", Automation in Construction, vol. 17, no. 2, pp. 163-179, 2008

[18] K. Kimoto, K. Endo, S. Iwashita, M. Fujiwara, "The application of PDA as mobile computing system on construction management", Automation in Construction, vol. 14, no.4, pp. 500-511, 2005.

[19] B. Kwon, "A Study on the Improvement of Current Construction Safety Management System", In-Cheon University, 2009.

[20] J. Lee, "Study on Application of Web-Based PDA System by an Analysis of Construction Confirmation Work Process in Public Apartment Project”, Han Yang University, 2010.
[21] K. Lee, H. Lee, M. Park, H. Kim, Y. Baek, "Development of Real Time Locating System for Construction Safety Management", Journal of Korea Institute of Construction Engineering and Management, vol. 11, no. 2, pp. 106-115, 2010.

[22] Ministry of Employment and Labor, "Analysis on industrial accidents 2007", pp. 1-12, 2007.

[23] I.O. Oh, C.S. Kim, J.S. Park, M.W. Pyeon, "Unit Technology Integration Scenario for the Application in Construction Work Sites", International Conference on Networked Computing and Advanced Information Management, pp. 472-477, 2010.

[24] J. Park, J. Lim, S. Kwon, "A Study on the Framework Construction of Mobile ERP System based on Smart-Phone", Journal of the Architectural Institute of Korea, vol. 26, n. 10, pp. 123-130, 2010.

[25] S. P. Peinado, A.J.V. Rico, J.V. Caon, J.J. de las Heras, J.M Mieres, "RFID-based Quality and Safety building site improvement during execution phase", 35th Annual Conference of IEEE Industrial Electronics, pp. 2659-2664, 2009.

[26] F. Pena-Mora, G.H. Dwivedi, "Multiple Device Collaborative and Real Time Analysis System for Project Management in Civi Engineering", Journal of Computing in Civil Engineering, vol. 16, no.1, pp.23-38, 2002.

[27] M. Schneider, "Radio Frequency Identification (RFID) Technology and its Applications in the Commercial Construction Industry”, University of Kentucky, 2003.

[28] H.P. Tserng, R. Dzeng, Y. Lin, S. Lin, "Mobile Construction Supply Chain Management Using PDA and Bar Codes", Computer-Aided Civil and Infrastructure Engineering, vol. 20, no. 4, pp. 242-264, 2005.

[29] Y. Yang, H. Choi, J. Kim, "Integrated operation method of safety checklist and schedule for construction accident prevention", Journal of Korea Institute of Construction Engineering and Management, vol. 5, no. 2, pp. 123-135, 2004

[30] D. Yeom, "An Investigation on the Current Safety Management System and Suggested Guide", Woosong University, 2008.

[31] X. Yu, V.P. Drnevich, "Mobile Computer for Portable Field Instrumentation System", ASCE GeoCongress 2006 : Geotechnical Engineering in the Information Technology Age, Atlanta, GA, USA, pp. 1-6, 2006. 